\title{
NEMATICIDE EFFECT OF VARIOUS ORGANIC SOIL AMENDMENTS ON Meloidogyne ethiopica WHITEHEAD, 1968, ON POTTED VINE PLANTS
}

\author{
Lucia Rivera $^{1}$, and Erwin Aballay ${ }^{*}$
}

\begin{abstract}
A B S T R A C T
Five organic soil amendments were evaluated for their nematicide effect on root-knot Meloidogyne ethiopica Whitehead, 1968, on potted Vitis vinifera L. var. Chardonnay plants. The amendments included two immature composts: Compost A made with tea (Camellia sinensis (L.) Kuntze) residues, broiler litter and grape pomace; Compost B made with tea residues, rachis and grape pomace; and separately dried tea residues, grape pomace and broiler litter. These amendments were either incorporated or applied as cover to the substrate in $5 \mathrm{~L}$ pots at the beginning of spring. A chemical treatment with the nematicide fenamiphos and a control with substrate only were added for comparisons. The assay was composed of 11 treatments with six replicates, with a grape plant as experimental unit. Seven months later, the assessment of the treatments was carried out based on number of second stage juvenile, nodules, eggs per root gram and reproductive index. Fresh aerial and root plant weight were also measured. The chemical treatment presented the lowest final population of $M$. ethiopica. When evaluating the nematicide action of the organic amendments, compost A soil-incorporated and both grape pomace and solid dry tea residue as covers obtained low reproductive indexes, similar to the chemical treatment and control $(\mathrm{P} \leq 0.05)$. No differences in aerial fresh weight were determined. However, the chemical treatment showed the smallest root mass as compared to compost B and solid dry tea residues, both as cover.
\end{abstract}

Key words: nematode control, compost, grape pomace, tea residues, chicken manure.

\section{INTRODUCTION}

Grapes are an economically important fruit crop in Chile. The area destined to vineyards is 179095 ha; of these $65 \%$ are for wine production and the rest for "pisco" (brandy) and table grapes (SAG, 2005). Crop damage caused by parasitic nematodes, often in association with plant pathogenic fungi and bacteria is common (Valenzuela and Aballay, 1996); it causes loss in plant vigor, quality and even plant death in sensitive varieties, such as Chardonnay. The control of plant parasitic nematodes is mainly done using chemical nematicides; but their use is being restricted due to risks to human health, environmental pollution and high costs.

Alternative strategies to control nematodes include crop rotation, resistant varieties and organic amendments (Ploeg, 2000). The latter are used because they add nutrients and organic matter to the soil and improve some of its physical properties, such as structure, drainage, aeration, water retention and also diminish erosion (McSorley and Gallaher, 1995).

The first effect of adding organic matter to the soil on perennial crops is a root system that increases plant tolerance towards nematodes (Stirling, 1991). A number of studies have reported on the direct effect of several organic amendments on plant parasitic nematodes (Mian and Rodriguez-Kabana, 1982a; 1982b; 1982c; Godoy et al., 1983; Rodriguez-Kabana et al., 1989; Rich and Hodge, 1993; Rodriguez-Kabana et al., 1995; D'Addabo and Sasanelli, 1998; Pandey, 2000; Oka and Yermiyahu, 2002).

Dry manure, the material most frequently used as organic amendment, generally contains large numbers of saprophytic nematodes (Gonzalez, 1991) and also liberates some organic compounds (e.g., butyric and

\footnotetext{
${ }^{1}$ Universidad de Chile, Facultad de Ciencias Agrícolas, Department of Crop Protection, Casilla 1004, Santiago, Chile.

E-mail: eaballay@uchile.cl._*Corresponding author.

Received: 5 April $2007 . \quad$ Accepted: 12 October 2007.
} 
propionic acids) and ammonia, which have nematicide activity (Kaplan and Noe, 1992; Hollis and RodriguezKabana, 1966). Results have been extremely varied as the effect of organic amendments on nematode populations depends on the source of the materials, their chemical composition, elaboration process, nematode species present and season of application (McSorley and Gallaher, 1996; Oka and Yermiyahu, 2002).

In Chile, fresh or composted organic materials are frequently used in vineyards to improve the development of roots infested with nematodes of the Meloidogyne, Xiphinema or Tylenchulus genera. However, no data are available concerning the effect of the materials used in Chile on these nematodes. The root-knot nematode, Meloidogyne ethiopica, a species recently reported to be widely distributed in Chilean vineyards (Carneiro et al., 2003) can cause serious damages, particularly to some wine grape varieties such as Chardonnay.

The aim of this study was to evaluate the effect of different organic amendments, currently used in vineyards, against $M$. ethiopica.

\section{MATERIALS AND METHODS}

The study was carried out in greenhouses in the Metropolitan Region, central Chile (32 $35^{\circ}$ ' to $34^{\circ} 19^{\prime}$ ' S, $69^{\circ} 46^{\prime}$ to $71^{\circ} 43^{\prime} \mathrm{W}$ ), beginning in October 2002. This region has a warm Mediterranean climate with winter rains and an extended dry season (7 to 8 months). Rooted 1-year-old cv. Chardonnay plants were planted in $5 \mathrm{~L}$ pots containing a sterile substrate made by mixing equal volumes of loamy soil, organic soil and sand. This substrate had a sandy loam texture, low organic matter content $(2.47 \%)$, slight salinity $(2.69 \%$ electric conductivity, EC), high $\mathrm{N}$ availability $(71 \mathrm{mg}$ $\left.\mathrm{kg}^{-1}\right)$, medium $\mathrm{P}$ availability $\left(15 \mathrm{mg} \mathrm{kg}^{-1}\right)$ and high $\mathrm{K}$ availability $\left(187 \mathrm{mg} \mathrm{kg}^{-1}\right)$.
The materials used in this study as soil amendments are frequently used in the Casablanca Valley, Valparaiso Region, Chile, a wine producing area with high infestation of several plant parasitic nematode species. The composts used were immature; this means that the organic matter passed through the mesophilic and thermophilic phases but not through the cooling and ripening phases (CONAMA, 2003).

The materials used were: 1) Compost A: immature compost, material prepared with equal parts of tea residues, broiler litter, and grape pomace, plus $10 \%$ soil, composted for 6 months; 2) Compost B: immature compost, material prepared with equal parts of sifted tea residues, rachis and grape pomace, plus $10 \%$ soil, composted for 6 months; 3) Tea residues: tea leaves and stems; 4) Grape pomace: residue from the previous year wine making process, grape skins and seeds, and 5) dry broiler litter.

The results of the physical and chemical analyses of materials used for $\mathrm{N}, \mathrm{P}_{2} \mathrm{O}_{5}, \mathrm{~K}_{2} \mathrm{O}$, organic matter $(\mathrm{OM})$, organic carbon (C) contents, humidity percentage, $\mathrm{pH}$, electrical conductivity (EC) and $\mathrm{C} / \mathrm{N}$ ratio are shown in Table 1. EC was measured according to the extract 1:5 method (Sadzawka et al., 2006).

Treatments evaluated were: T1: Compost A mixed with the substrate at $500 \mathrm{~g} \mathrm{pot}^{-1} ; \mathrm{T} 2$ : Compost A on top of the substrate at $500 \mathrm{~g} \mathrm{pot}^{-1} ; \mathrm{T} 3$ : Compost B mixed with the substrate at $500 \mathrm{~g} \mathrm{pot}^{-1} ; \mathrm{T} 4$ : Compost B on top of the substrate at $500 \mathrm{~g} \mathrm{pot}^{-1} ; \mathrm{T} 5$ : Tea residues mixed with the substrate at $500 \mathrm{~g} \mathrm{pot}^{-1}$; T6: Tea residues on top of the substrate at $500 \mathrm{~g} \mathrm{pot}^{-1}$; T7: Grape pomace mixed with the substrate at $500 \mathrm{~g} \mathrm{pot}^{-1}$; T8: Grape pomace on top of the substrate at $500 \mathrm{~g} \mathrm{pot}^{-1}$; T9: Fenamiphos (Nemacur $400 \mathrm{EC}$ ) at $0.4 \mathrm{~mL}$ of a.i. pot ${ }^{-1}$, watering up to saturation; T10: Dry broiler litter mixed with the substrate at $500 \mathrm{~g} \mathrm{pot}^{-1}$; and T11: Control.

Table 1. Physico-chemical properties of the organic amendments used.

\begin{tabular}{|c|c|c|c|c|c|c|c|c|c|}
\hline Amendments & $\mathbf{N}$ & $\mathbf{P}_{2} \mathbf{O}_{5}$ & $\mathrm{~K}_{2} \mathrm{O}$ & pH & EC & OM & Organic C & Humidity & $\mathrm{C} / \mathrm{N}$ \\
\hline & & $\%$ & & & $\mathrm{dS} \mathrm{m}^{-1}$ & & $\%$ & & \\
\hline Compost A & 0.44 & 0.71 & 0.38 & 7.40 & 1.10 & 12.00 & 7.00 & 12.50 & 15.90 \\
\hline Compost B & 1.28 & 0.87 & 0.76 & 6.85 & 1.25 & 38.70 & 22.50 & 18.70 & 17.60 \\
\hline Tea residues & 4.10 & 0.53 & 0.07 & 5.70 & 3.60 & 92.70 & 53.90 & 64.70 & 13.15 \\
\hline Grape pomace & 2.45 & 0.96 & 4.08 & 7.60 & 3.30 & 87.70 & 51.00 & 60.50 & 20.80 \\
\hline Broiler litter & 2.42 & 3.23 & 1.82 & 6.50 & 9.30 & 52.30 & 30.40 & 9.10 & 12.60 \\
\hline
\end{tabular}

EC: electrical conductivity; OM: organic matter; C: carbon. 
Dosages for the amendments were equivalent to $20 \%$ $(\mathrm{v} / \mathrm{v})$ of the substrate volume. Treatments were applied one day before inoculation of plants with $2000 \mathrm{M}$. ethiopica eggs pot ${ }^{-1}$. Control received only inoculum. Inoculum was obtained from a Chardonnay vineyard in Casablanca severely infested with this nematode species. Eggs were extracted using Hussey and Barker's (1973) method. At the beginning of spring, the inoculum was added to five $10 \mathrm{~cm}$ deep holes located $6 \mathrm{~cm}$ away from the plant. The experiment was arranged in a randomized complete design with 11 treatments and six replicates per treatment. The pots were placed in a greenhouse and the plants grown for 7 months and watered regularly to keep the soil at field capacity. No fertilizer was applied.

Plants were removed from the pots in May. The fresh weight of roots and new shoot growth, number of galls and number of eggs per root system extracted according to Husey and Barker's method (1973), were determined. Second stage juveniles (j2) were extracted from the soil using the modified Cobb's sieve method (Southey, 1986) with 180, 75 and $45 \mu \mathrm{m}$ sieves. The material obtained after sieving was placed on a Baermann funnel for $48 \mathrm{~h}$; the nematodes were counted at $90 \mathrm{X}$ with a light microscope (Carl Zeiss, Stemi 2000-C, Göttingen, Germany).

The nematode reproduction index was calculated as $\mathrm{R}=\mathrm{Pf} / \mathrm{Pi}$, where $\mathrm{Pf}=$ (number of eggs per root system + number of $\mathrm{j} 2$ per pot) and $\mathrm{Pi}=2000$ eggs pot $^{-1}$. Statistical significance of differences between treatments was determined by ANOVA procedures $\mathrm{P}$ $=0.05$; means were separated using Tukey's Multiple Comparison Test.

\section{RESULTS AND DISCUSSION}

Chemical treatment significantly reduced nematode multiplication, infestation and galling of grapes roots as compared to the control (Table 2). However, the final population was not reduced. Most other treatments did not differ from control, only second stage larvae were affected by four of the treatments besides the chemical one.

Similarly and concerning plant growth significant differences were produced only for shoot weight between control and compost B in cover (Table 3). No differences were detected in root weight. The results reflected a positive correlation between root weight and number of nodules present, thus a root with a high number of nodules would also show a weight increase. On the other hand, the chemical treatment had the lowest root weight, showing a significant difference with the Compost B treatment and those of tea residues in cover.

Concerning the reproductive index (R), the chemical treatment showed the lowest value being statistically different to control. Compost A soil-incorporated, grape pomace in cover, tea residues in cover, tea residues

Table 2. Effect of organic amendments on Meloidogyne ethiopica associated to grape vines.

\begin{tabular}{|c|c|c|c|c|}
\hline Treatments & Eggs per root & Nodules per root & $2^{\text {nd }}$ stage larvae per pot & $\mathbf{R}(\mathbf{P f} / \mathbf{P i})$ \\
\hline Compost A soil-incorporated & $55.2 \mathrm{abc}$ & $3.1 \mathrm{ab}$ & $441.6 \mathrm{ab}$ & $3.0 \mathrm{ab}$ \\
\hline Compost $\mathrm{A}$ in cover & $17.2 \mathrm{abc}$ & $6.3 \mathrm{abc}$ & $868.8 \mathrm{abc}$ & $7.3 b$ \\
\hline Compost B soil-incorporated & $99.8 \mathrm{abc}$ & $10.4 d$ & $1022.4 b c$ & $6.2 \mathrm{ab}$ \\
\hline Compost $\mathrm{B}$ in cover & $95.3 \mathrm{abc}$ & $9.2 \mathrm{~d}$ & $801.6 \mathrm{abc}$ & $8.5 \mathrm{~b}$ \\
\hline Tea residues soil-incorporated & $94.8 \mathrm{abc}$ & $7.2 \mathrm{bcd}$ & $902.4 \mathrm{abc}$ & $6.2 \mathrm{ab}$ \\
\hline Tea residues in cover & $45.2 \mathrm{ab}$ & $3.8 \mathrm{bcd}$ & $504.0 \mathrm{ab}$ & $3.5 \mathrm{ab}$ \\
\hline Grape pomace soil-incorporated & $289.0 \mathrm{~d}$ & $8.4 \mathrm{~cd}$ & $585.6 \mathrm{ab}$ & $16.0 \mathrm{c}$ \\
\hline Grape pomace in cover & $51.7 \mathrm{abc}$ & $2.3 \mathrm{ab}$ & $379.2 \mathrm{a}$ & $3.4 \mathrm{ab}$ \\
\hline Chemical treatment & $21.8 \mathrm{a}$ & $1.5 \mathrm{a}$ & $369.6 \mathrm{a}$ & $1.1 \mathrm{a}$ \\
\hline Broiler litter & $145.2 \mathrm{c}$ & $6.8 \mathrm{bcd}$ & $806.4 \mathrm{abc}$ & $8.4 \mathrm{~b}$ \\
\hline Control & $136.4 \mathrm{bc}$ & $6.9 \mathrm{bcd}$ & $1334.4 \mathrm{c}$ & $7.7 \mathrm{~b}$ \\
\hline
\end{tabular}

Means in a column with the same letter are not statistically different, according to Tukey's test $(\mathrm{P} \leq 0.05)$.

Compost A: tea residues, broiler litter and crushed grape pomace; Compost B: tea residues, and crushed cluster and grape pomace.

R: reproductive index; Pf: final population per pot, including eggs plus stage 2 juveniles, 7 months after treatment; Pi: initial population, 2000 eggs pot $^{-1}$. 
soil-incorporated and Compost B soil-incorporated treatments were statistically equal to the chemical treatment. However, the final population increased in all treatments (Table 2).

Comparing the results of both grape pomace soilincorporated and in cover treatments, the last showed a lower reproductive index $(\mathrm{R})$, number of nodules per root and number of eggs per root (Table 2).

The nematicide effect of grape pomace may be related to the release of compounds such as ammonia $\left(\mathrm{NH}_{3}\right)$, polyphenols and tannins from the berry epidermis. This tissue represents $7-12 \%$ of the weight of the berry, which is $78-80 \%$ water, $0.8-1.6 \%$ organic acids, $0.4-3.0 \%$ tannins, $0.0-0.5 \%$ antocianins, $1.5-2.0 \%$ nitrogenous compounds, $1.5-2.0 \%$ minerals, and $1.0-2.0 \%$ waxes (Flanzy, 2000).

In this study, the $\mathrm{pH}$ of grape pomace was 7.6 (Table 1), thus considered slightly alkaline (SSS, 1993). This factor is of great importance for the liberation and stability of ammonia in the soil atmosphere, since under basic $\mathrm{pH}$ conditions there is a large amount of free ammonia in water (Oka and Pivonia, 2002). For grape pomace the $\mathrm{C} / \mathrm{N}$ proportion was 20.8 (Table 1 ), bordering the optimal range (14-20) at which nematicide activity takes place without causing toxicity to plants (Stirling, 1991).
Materials with high polyphenols contents, as grape pomace and tea residues, have been used as organic amendments to control plant parasitic nematodes, by way of altering root attractiveness to nematodes (Stirling, 1991). In Sitaramaiah and Singh (1978) study, neem (Azadirachta indica A. Juss.) cake, saltree sawdust (Shorea robusta C.F. Gaertn.) and rosewood (Dalbergia sissoo Roxb. ex DC.), and when supplemented with NPK fertilization, increased the phenolic content of the soil. Tomato (Lycopersicon esculentum Mill.) roots growing in amended soil had a higher level of total phenols than those growing in not amended soil. When exposing females of $M$. javanica to benzoic, phenyl butyric, phenyl acetic and cinamic acids, their capacity for laying eggs decreased significantly; also one of the main direct effects of these acids was the suppression of mobility in $M$. javanica larvae. When exposing tomato roots to different concentrations of these acids, certain resistance was found to nematode invasion, as scarce numbers of larvae were capable of penetrating the roots and develop to adults and thus few eggs originated. The results suggested that the presence of such compounds on the roots growing in amended soils would be a reason for the suppression of $M$. javanica and other nematodes. Thus, resistance of the plant to nematode development and infestation would be correlated to the phenols level in the roots and has been credited with delaying the formation of giant cells and poor nutrition of larvae.

Table 3. Effect of treatments on some plant vigor parameters.

\begin{tabular}{lcc}
\hline Treatments & Shoot weight & Root weight \\
\cline { 2 - 3 } Compost A soil-incorporated & $41.7 \mathrm{ab}$ & $\mathrm{g}$ \\
Compost A in cover & $36.8 \mathrm{ab}$ & $100.1 \mathrm{bc}$ \\
Compost B soil-incorporated & $42.3 \mathrm{ab}$ & $119.3 \mathrm{abc}$ \\
Compost B in cover & $35.1 \mathrm{ab}$ & $116.9 \mathrm{abc}$ \\
Tea residue soil-incorporated & $32.8 \mathrm{~b}$ & $168.1 \mathrm{a}$ \\
Tea residue in cover & $38.3 \mathrm{ab}$ & $120.9 \mathrm{abc}$ \\
Grape pomace soil-incorporated & $40.8 \mathrm{ab}$ & $140.9 \mathrm{ab}$ \\
Grape pomace in cover & $45.9 \mathrm{a}$ & $112.1 \mathrm{bc}$ \\
Chemical treatment & $39.3 \mathrm{ab}$ & $120.9 \mathrm{abc}$ \\
Broiler litter & $39.5 \mathrm{ab}$ & $84.1 \mathrm{c}$ \\
Control & $40.0 \mathrm{ab}$ & $110.1 \mathrm{bc}$ \\
\hline
\end{tabular}

Means in a column with the same letter are not statistically different according to Tukey's test $(\mathrm{P} \leq 0.05)$.

Compost A: tea residues, chicken manure and crushed grape pomace; Compost B: tea residues, and crushed cluster and grape pomace. 
The significant differences between cover and soilincorporated grape pomace would be explained from the irrigation method used. Irrigation was done with a hand watering can. Thus, adding water permanently may have caused some lixiviation of tannins towards the roots and the remaining could have facilitated a permanent suppressing effect on the nematodes populations. On the contrary, when this material was incorporated to the soil, tannins would become fixed to the organic matter, forming complexes with proteins, carbohydrates and ions that would lead to a lesser nematode suppression effect. The formation of the protein-tannin complex has a deep effect upon the $\mathrm{N}$ cycle, reducing lixiviation and $\mathrm{N}$ availability for some plant species (Engelke et al., 2000).

Concerning the solid tea residue organic amendment, although cover application was apparently more effective on some parameters than the same residue soil-incorporated, there were no statistical differences between treatments. These variations may be explained in the same way as those of grape pomace: due to lixiviation of tannins through irrigation when the amendment was applied as cover and to tannin fixation to the organic matter when tea residues were soil incorporated.

The $\mathrm{pH}$ of the solid tea residues was of 5.7 defined by SSS (1993) as moderately acid, hindering the release and posterior action of ammonia on the nematodes. It also had a high $\mathrm{N}$ content and a low $\mathrm{C} / \mathrm{N}$ proportion (Table 2).

Soil-incorporated Compost A (tea, broiler litter, and grape pomace) showed a median of nodules and $\mathrm{R}$ index not significantly different from the cover treatment. However, its nematicide effects over second stage larvae would be due mainly to the release of ammonia in a slightly alkaline $\mathrm{pH}$ and a $\mathrm{C} / \mathrm{N}$ proportion within the optimal range, according to Stirling (1991).

None of the evaluated parameters differed statistically between cover and soil-incorporated Compost B treatments (tea, grape rachis and grape pomace). As in Compost A, Compost B soil-incorporated presented a similar $\mathrm{R}$ than chemical treatment. Some of the nematicide effects of Compost $\mathrm{B}$ would be due to its high level of $\mathrm{N}$ and $\mathrm{C} / \mathrm{N}$ proportion, within the optimal range according to Stirling (1991) (Table 2).

The evaluated parameters did not differ between broiler litter and the control treatment; this might be related to the slightly acid $\mathrm{pH}$ and low $\mathrm{C} / \mathrm{N}$ proportion of this material. Gonzalez (1991) obtained similar results, where applications of manure did not produce an adequate level of control of plant parasitic nematodes, establishing that this treatment could be complementary to, but would not replace chemical controls. However, Muller and Gooch (1982) obtained opposing results when applying pre-planting chicken manure on tomato, reducing populations of Meloidogyne spp.

Although the chemical treatment was the most effective to reduce nematodes populations, it also affected root growth negatively. This could be due to a certain phytotoxic effect of fenamiphos, similar to that reported by Bunt (1975) who evaluated the effect of four nematicides, including fenamiphos, on tomato seedlings inoculated with Ditylenchus dipsaci. The results indicated toxicity to the leaves at $16 \mathrm{mg} \mathrm{L}^{-1}$ and symptoms on leaves, stems and roots at $64 \mathrm{mg} \mathrm{L}^{-1}$ of solution

It is not superfluous to believe that the suppressing activity by some of the organic materials used might be due to the participation of microorganisms such as bacteria and fungi (Stirling, 1991; Oka and Yermiyahu, 2002).

\section{CONCLUSIONS}

The use of composts prepared with tea residues, broiler litter and grape pomace incorporated to the soil; grape pomace in cover alone; tea residues in cover or soilincorporated and compost made of tea residues, grape rachis and grape pomace soil-incorporated, shows a suppressing effect against $M$. ethiopica, with a degree of significance comparable to that of the chemical treatment.

In general, the form of application of organic amendments, as a cover or soil-incorporated, did not cause a variation in population of nematodes except with grape pomace amendment.

Finally, the absence of differences in the aerial vigor parameter between the treatments and the control may be due to the fact that nematodes populations do not reach maximum levels in one season ( 7 months) and a decrease in shoot weight would not be yet evident. However, grape plants infested with Meloidogyne spp. may decrease their production potential, particularly those of cv. Chardonnay, a variety especially susceptible to this genus. 


\section{R E S U M E N}

Efecto nematicida de varias enmiendas orgánicas sobre Meloidogyne ethiopica Whitehead, 1968, en plantas de vid en macetas. Lucia Rivera ${ }^{1}$, y Erwin Aballay ${ }^{1^{*}}$. Se realizó un experimento en macetas con plantas enraizadas de Vitis vinifera L. var. Chardonnay para evaluar el efecto nematicida de diferentes enmiendas orgánicas sobre el nematodo agallador Meloidogyne ethiopica Whitehead, 1968. Se usaron dos composts inmaduros: Compost A, elaborado con residuos de té (Camellia sinensis (L.) Kuntze, guano de pollo seco y orujo de uva; Compost B, elaborado con residuos de té, escobajo y orujo de uva; y separadamente residuos sólidos de té; orujo de uva y guano de pollo seco. Estas enmiendas fueron aplicadas a principio de primavera, tanto en cobertera como incorporadas al suelo, considerando además un testigo químico fenamiphos y un testigo absoluto. Se determinó la población de nematodos de segundo estado juvenil (estado infestivo) de Meloidogyne spp., la cantidad de nódulos, huevos por gramo de raíz y el índice reproductivo, determinando de esta manera la tasa de reproducción de los nematodos. Además se evaluó el peso fresco de la parte aérea y de la masa radical. El testigo químico fue el tratamiento que obtuvo menor población final de Meloidogyne spp., y al evaluar la actividad nematicida de las enmiendas orgánicas, el Compost A incorporado al suelo, orujo de uva en cobertera y residuos sólidos de té en cobertera obtuvieron índices reproductivos bajos, que no fueron estadísticamente diferentes del testigo químico. En el peso fresco de la parte aérea no hubo diferencias significativas. El peso fresco de la masa radical del testigo químico presentó el valor más bajo comparado con los tratamientos de Compost B en cobertera y residuos sólidos de té en cobertera.

Palabras clave: control de nematodos, compost, orujo de uva, residuos? De té, guano de pollo.

\section{LITERATURE CITED}

Bunt, J.A. 1975. Effect and mode of action of some systemic nematicides. Communication 75-100. 127 p. Agricultural University, Department of Nematology, Wageningen, The Netherlands.

Carneiro, R.M.D.G., C.B. Gomez, M.R. Almeida, A.C.M.M. Gomez, e I. Martins. 2003. Primeiro registro de Meloidogyne ethiopica Whitehead, 1968, em plantas de quivi no Brasil e reação em diferentes plantas cultivadas. Nematol. Bras. 27:151-158.

CONAMA. 2003. Norma de calidad del compost, clasificación y requisitos. [En línea]. Comisión Nacional del Medio Ambiente (CONAMA), Santiago, Chile. Disponible en http://www.conama.cl/rm/568/articles28706_recurso_2.pdf (Leído 2 septiembre 2004).

D'Addabo, T., and N. Sasanelli. 1998. The suppression of Meloidogyne incognita on tomato by grape pomace soil amendments. Nematologia Mediterranea 26:145149.

Engelke, C.J., H. Knicker, and I. Kögel-Knabner. 2000. Characterization of condensed tannins in soil by mean of mass spectrometry - a novel approach investigating structure and function. [On line] Available at http:// www.imog.agh.edu.pl/website/ program/session/oral/ pdf/oix-2.pdf (Accessed 20 October 2004).

Flanzy, C. 2000. Enología: Fundamentos científicos y tecnológicos. 389 p. Mundi-Prensa, Madrid, España.
Godoy, G.R., R. Rodriguez-Kabana, A. Shelby, and G. Morgan-Jones. 1983. Chitin amendments for control of Meloidogyne arenaria in infested soil. Nematropica 13:63-74.

González, H. 1991. La materia orgánica en la reducción de nematodos fitoparásitos. Investigación y Progreso Agropecuario La Platina $\mathrm{N}^{\circ} 65$ p. 17-21.

Hollis, J.P., and R. Rodriguez-Kabana. 1966. Rapid kill of nematodes in flooded soil. Phytopathology 56:1015-1019.

Hussey, R.S., and K.R. Barker. 1973. A comparison of methods of collecting inocula of Meloidogyne spp., including a new technique. Plant Dis. Rep. 57:10251028.

Kaplan, M., and J.P. Noe. 1992. Effect of chickenexcrement amendments on Meloidogyne arenaria. J. Nematol. 25:71-77.

McSorley, R., and R.N. Gallaher. 1995. Cultural practices improve crop tolerance to nematodes. Nematropica 25:53-60.

McSorley, R., and R.N. Gallaher. 1996. Effect of yard waste compost on nematode densities and maize yield. J. Nematol. 28:655-660.

Mian, I.H., and R. Rodriguez-Kabana. 1982a. Soil amendments with oil cakes and chicken litter for control of Meloidogyne arenaria. Nematropica 12:205-220. 
Mian, I.H., and R. Rodriguez-Kabana. 1982b. Organic amendments with high tannin and phenolic contents for control of Meloidogyne arenaria in infested soil. Nematropica 12:221-234.

Mian, I.H., and R. Rodriguez-Kabana. 1982c. Survey of the nematicidal properties of some organic materials available in Alabama as amendments to soil for control of Meloidogyne arenaria. Nematropica 12:235-246.

Muller, R., and P.S. Gooch. 1982. Organic amendments in nematode control: an examination of the literature. Nematropica 12:319-326.

Oka, Y., and S. Pivonia. 2002. Use of ammonia-releasing compounds for control of the root-knot nematode Meloidogyne javanica. Nematology 4:65-71.

Oka, Y., and U. Yermiyahu. 2002. Suppressive effects of composts against the root-knot nematode Meloidogyne javanica on tomato. Nematology 4:891-898.

Pandey, R. 2000. Additive effect of three organic materials and nematicides on the reproduction of Meloidogyne incognita and yield of Mentha arvensis. Nematropica 30:154-160.

Ploeg, T. 2000. Effects of amending soil with Tagetes patula cv. Single Gold on Meloidogyne incognita infestation of tomato. Nematology 2:289-493.

Rich, J., and C.H. Hodge. 1993. Utilization of blue crab scrap compost to suppress Meloidogyne javanica on tomato. Nematropica 23:1-5.

Rodriguez-Kabana, R., D. Boube, and R.W. Young. 1989. Chitinous materials from blue crab for control of rootknot nematode. Nematropica 19:53-74.
Rodriguez-Kabana, R., V. Estaun, J. Pinochet, and O. Marfa. 1995. Mixtures of olive pomace with different nitrogen sources for the control of Meloidogyne spp. on tomato. J. Nematology (Supplement) 27:575-584.

SAG. 2005. Catastro vitícola nacional. 51 p. Ministerio de Agricultura, Servicio Agrícola y Ganadero (SAG), Departamento de Protección Agrícola, Sub-Departamento Viñas y Vinos, Santiago, Chile.

Sadzawka R., A, M.A. Carrasco R., R. Grez Z., M.L. Mora G., H. Flores P., y A. Neaman. 2006. Métodos de análisis de suelos recomendados para los suelos de Chile. Revisión 2006. Serie Actas INIA No 34. 164 p. Instituto de Investigaciones Agropecuarias, Santiago, Chile,

Sitaramaiah, K., and R.S. Singh. 1978. Effect of organic amendment on phenolic content of soil and plant and response of Meliodogyne javanica and its host to related compounds. Plant Soil 50:671-679.

Southey J.F. 1986. Laboratory methods for work with plant and soil nematodes. Ministry of Agriculture, Fisheries and Food, Reference Book 402. Her Majesty's Stationary Office, London, UK.

SSS. 1993. Soil survey manual. 437 p. USDA, Soil Survey Division Staff, Washington D.C., USA.

Stirling, G.R. 1991. Biological control of plant-parasitic nematodes: Progress, problems and prospects. 275 p. $\mathrm{CAB}$ International, Wallingford, UK.

Valenzuela, A., y E. Aballay. 1996 Evaluación del control químico de Xiphinema index en vides. Nematropica 26:177-179. 